\title{
A HIPÓTESE DA INSTABILIDADE FINANCEIRA E SUAS IMPLICAÇÕES PARA A OCORRÊNCIA DE CICLOS ECONÔMICOS*
}

\author{
Thaiza Regina Bahry ${ }^{* *}$
}

\section{Luciano Ferreira Gabriel ${ }^{* * *}$}

\begin{abstract}
RESUMO O presente artigo tem por objetivo a utilização do arcabouço teórico minskyano para o entendimento da fragilidade financeira observada, recentemente, em parte do sistema financeiro dos Estados Unidos. Pretende-se, ainda, sugerir uma interpretação da dinâmica cíclica de tal economia a partir da influência do mercado imobiliário sobre o nível de consumo e investimento. Procurar-se-á demonstrar que a fragilização da estrutura financeira de determinados agentes foi em grande medida endógena, dada a adoção de posturas financeiras crescentemente alavancadas. Contudo, apesar da endogeneidade do processo, verificar-se-á que a reversão da tendência econômica se iniciou por meio de um choque exógeno, a partir da elevação da taxa de juros básica, submetendo vários agentes econômicos a uma configuração especulativa e Ponzi, contaminando diversos setores da economia.
\end{abstract}

Palavras-chave: Minsky; hipótese da instabilidade financeira; crise imobiliária; Estados Unidos; reversão cíclica

Código JEL: E30; E44; E58; G21

\footnotetext{
* Artigo recebido em 7 de fevereiro de 2008 e aprovado em 10 de setembro de 2009. Os autores agradecem os comentários e as sugestões de dois pareceristas anônimos deste periódico. No entanto, as ideias expostas no artigo são de inteira responsabilidade dos autores, assim como eventuais erros e omissões.

** Doutora em Economia pelo PPGDE-UFPR. Professora da Universidade Positivo — UP e do Complexo de Ensino Superiores do Brasil — Unibrasil, e-mail: thaiza@up.eu.br

*** Mestre em Economia pelo PPGDE-UFPR. Professor do Complexo de Ensino Superiores do Brasil - Unibrasil. Pesquisador do periódico Economia \& Tecnologia do Cepec-UFPR e economista da Fiep (Federação das Indústrias do Estado do Paraná), e-mail: lucianofg@gmail.com
} 


\title{
THE FINANCIAL INSTABILITY HYPOTHESIS AND ITS IMPLICATIONS TO THE ECONOMIC CYCLES
}

\begin{abstract}
The aim object of this paper is to analyze USA house credit market in a financial system from Minskyan background. By this perspective, it is suggested a way to understand the cyclical dynamics of the house mortgage debt on consume, investment and economic growth. It will be demonstrated that the frail financial household structure was in great measure an endogenous process, given the adoption of financial postures increasingly leveraged. However, in spite of the endogenous process, it will be verified that the reversion of the economical tendency began through an exogenous shock, starting from the rise of the basic interest rate of the economy, submitting several economical agents to a speculative and Ponzi configuration, affecting several market sectors.
\end{abstract}

Key words: Minsky; financial instability hypothesis; mortgage crisis; United States; reversal cyclical 


\section{INTRODUÇÃO}

A obra de Hyman P. Minsky é considerada para diversos autores, como Daziel (1999) e Dymski (1998 e 2004), uma das maiores contribuições em teoria monetária e financeira do século passado. A importância e robustez da teoria desse autor derivam-se, em grande medida, da adaptabilidade da hipótese da instabilidade financeira das economias de mercado às mudanças do marco regulatório e institucional pelo qual passa o modo de produção capitalista. Nesse sentido, a contribuição de Minsky e demais pesquisadores dessa abordagem histórico-institucional, alicerçada em suas perspectivas fundamentais, fornece singular método de análise da dinâmica do sistema capitalista, na medida em que incorpora em seu tratamento: (a) a fragilidade financeira/instabilidade financeira no contexto das economias fechadas e abertas; $^{1}$ (b) a mudança do marco histórico e institucional do sistema financeiro das economias; (c) a questão — apesar de inconclusa - do tipo de trajetória dinâmica concernente à modelagem da instabilidade financeira das economias contemporâneas.

As contribuições à la Minsky focalizam os fenômenos monetários e financeiros na interpretação do funcionamento das economias capitalistas consideradas, as quais se constituem em “(...) um complexo de instituições financeiras e múltiplas ligações entre os mercados financeiros, de trabalho e de produtos e os fluxos de renda" (Minsky, 1994, p. 22).

O presente artigo não pretende tratar a evolução, diferentes fases e alterações de percurso de Minsky. Seu objetivo, mais restrito, é utilizar o arcabouço teórico, a partir da hipótese da instabilidade financeira e demais contribuições dessa ampla linha de pesquisa, para o entendimento do fenômeno verificado, recentemente, na economia estadunidense, a partir da fragilidade financeira observada em parte do sistema bancário e dos tomadores de recursos no setor imobiliário. Ao mesmo tempo, pretende-se sugerir uma interpretação sobre a dinâmica cíclica daquela economia a partir da influência do mercado imobiliário sobre o nível de consumo e investimento.

Isso posto, procurar-se-á explorar, a partir das evidências encontradas, que a fragilização da estrutura financeira de determinados agentes econômicos foi em grande medida endógena, refletindo a interação entre um período expansivo, exacerbação do otimismo das expectativas desses mesmos 
agentes e intermediários financeiros, os quais adotaram posturas financeiras crescentemente especulativas e alavancadas dentro de um contexto de grande permissividade da regulação da estrutura financeira no mercado em estudo. Contudo, apesar dessa endogeneidade do processo, verificar-se-á que a reversão da tendência econômica se iniciou por meio de um choque exógeno, a partir de mudanças da política econômica, com a elevação da taxa de juros básica da economia pelo Federal Reserve (EUA), submetendo a uma configuração especulativa e Ponzi vários agentes econômicos, contaminando demais setores e bancos da economia.

Em termos teóricos, essa dinâmica mista é desenvolvida por Dymski e Pollin (1998) e Dymski (2004), como será destacado na seção 2. Contudo, apesar de Minsky sugerir que a instabilidade e a incoerência das economias capitalistas eram endógenas, a interpretação dessa endogeneidade tem observado certo grau de diferença dentre aqueles pesquisadores que compartilham de parte basilar de sua teoria. Ao contrário de Dymski e Pollin (1992) e também Dymski (2004), Ferri (1992) advoga que os ciclos econômicos advêm de fatores completamente endógenos. Como aponta Lourenço (2006), isso não quer dizer que não ocorram choques exógenos, mas apenas que eles não se consubstanciam em condição necessária para que reversões cíclicas ocorram.

Como é apresentado na seção 1, a concepção utilizada de ciclo no presente artigo não significa a antítese do equilíbrio dos modelos econômicos. Muito menos, dado o caráter não linear da economia, se refere a aspectos de regularidade e simetria (como na ideia de um ciclo limite). De acordo com a tradição de Hyman P. Minsky, destacado por Minsky (1975), Dymski e Pollin (1998), Dymski (2004) e Lourenço (2006), o ciclo se refere a uma sucessão de estados transitórios (como períodos de boom econômico, crise e deflação de ativos), cuja ênfase se encontra na transição, sucessão e recorrência desses estados, e não na sua regularidade temporal e simetria. $\mathrm{Na}$ seção 2 apresentam-se a geração e o desencadeamento de uma crise econômica em termos minskyanos, bem como discute-se o significado de ciclo econômico. Na sequência é realizada uma análise do mercado de crédito imobiliário estadunidense, e na seção 4 é apresentado como esse setor influenciou o crescimento do produto, investimento e consumo, a partir do enquadramento de diversos agentes econômicos em posturas financeiras 
Ponzi e especulativa. Além disso, na seção 5 também é sugerido um esquema analítico para o entendimento da crise em uma economia aberta. E, por fim, são delineadas algumas considerações finais.

\section{INVESTIMENTO, FINANCIAMENTO E INSTABILIDADE FINANCEIRA}

A hipótese da instabilidade financeira desenvolvida por Minsky é uma interpretação e aprofundamento de alguns pontos da Teoria geral, de John Maynard Keynes, que o autor considera fundamentais para explicar o funcionamento da economia moderna. Sua ênfase encontra-se nas questões financeiras, na instabilidade do desenvolvimento capitalista e na articulação existente entre estas.

Assim como Keynes e também Kalecki, ${ }^{2}$ Minsky percebe que a relação entre investimento e poupança pode dar origem a ciclos econômicos. Keynes, em especial, ao observar que os agentes econômicos diminuem seu nível de liquidez em períodos de crescimento econômico e de alta do valor dos ativos, constata que eles buscam recuperá-la quando essas variáveis invertem sua tendência, observando uma fonte financeira para reversão cíclica. Contudo, é Minsky quem expõe mais claramente essa questão.

Minsky (1975) demonstra que, assim como as expectativas dos agentes econômicos mudam de acordo com o estágio do ciclo econômico, as relações de balanço econômico-financeiro e contábil se alteram ao longo desse mesmo ciclo. Como destacam Dymski (2004) e Kregel (2007), no início esses balanços apresentam solidez porque os preços dos ativos são estabelecidos de maneira conservadora e as dívidas assumidas são pequenas em relação a estes ativos. Na fase de crescimento econômico, porém, os preços dos ativos sobem e cresce o peso da dívida, até que os níveis de endividamento das firmas superam a rentabilidade dos ativos e uma desaceleração econômica é, então, induzida. ${ }^{3}$ Em seguida, cai o valor dos ativos e pode desencadear-se um ciclo de deflação de dívidas (e também de demais ativos).

Conforme a hipótese da instabilidade financeira, a economia capitalista caracteriza-se por um sistema financeiro sofisticado e complexo, e seu desenvolvimento ocorre acompanhado por trocas de dinheiro presente por dinheiro futuro. ${ }^{4}$ É uma economia inerentemente instável, que apresenta um endividamento crescente em função de sua necessidade de financiar o 
investimento em um ambiente de crédito barato, o que faz com que, de tempos em tempos, gere inflações e deflações de dívidas. Desse modo, mostra um comportamento cíclico, em que todos os ciclos são gerados endogenamente e são transitórios. ${ }^{5}$

A hipótese da instabilidade financeira tem seu fundamento na existência de dois conjuntos de preços na economia: o preço de oferta e o preço de demanda dos ativos de capital. ${ }^{6} \mathrm{O}$ preço de oferta depende das taxas de salário em dinheiro, da produtividade do trabalho com os ativos de capital existentes, do markup aplicado sobre os custos e do custo de financiar a produção. O preço de demanda de um ativo de capital é determinado pela oferta e demanda em seu mercado, em que a oferta é estabelecida no período corrente e a demanda reflete a quase renda ${ }^{7}$ que se espera que o ativo ofereça ao longo do tempo (Minsky, 1986). "Assim, para uma oferta fixa de ativos de capital num determinado momento, existe um preço, determinado pela demanda, que é uma proxy do preço resultante da capitalização dos rendimentos futuros, realizada subjetivamente pelos agentes econômicos" (Deos, 1997, p. 40). Esse preço depende da liquidez do ativo, isto é, da facilidade e da segurança com que pode ser transformado em dinheiro, e da quase renda esperada da utilização do ativo de capital. É também uma função positiva da quantidade de moeda em circulação. ${ }^{8}$

Quando o nível de preços de demanda é alto em relação ao nível de preços de oferta, as condições são favoráveis ao investimento. Já em casos em que o preço de oferta é superior ao preço de demanda, os investidores, em vez de adquirir novos bens de capital, passam a adquirir os similares já existentes no mercado.

Entretanto, o preço de demanda não determina sozinho a trajetória do investimento, pois a demanda efetiva necessita de financiamento. Com efeito, planejar um projeto de investimento envolve duas decisões: a primeira está relacionada à renda esperada do uso do ativo de capital na produção e aos custos do investimento; a segunda está associada ao financiamento do ativo.

Relativamente ao financiamento, existem três fontes de recursos: os ativos financeiros e dinheiro no portfólio que não são utilizados nas operações correntes, isto é, os recursos líquidos; os fundos internos, em outras palavras, a quase renda gerada durante o período de investimento; e os recursos 
externos à empresa, que podem ser obtidos pela emissão de ações ou adquiridos junto a bancos ou outros intermediários financeiros. Os fundos internos disponíveis para financiar um investimento necessitam ser aumentados pelos fundos externos, na insuficiência dos primeiros. Dessa forma, a disponibilidade de fundos externos é um elemento fundamental para a decisão de investir. Contudo, tomar um empréstimo exige o pagamento de compromissos, o qual determina um mínimo de fluxo de dinheiro requerido para satisfazer as obrigações legais da unidade que adquire o financiamento.

A concessão de empréstimos é determinada, fundamentalmente, tendo em vista as margens de segurança (safety margins) quanto à capacidade de pagamento do agente tomador de empréstimos. Essas estão referenciadas nas fontes de pagamento do agente que se endivida, isto é, nas fontes primárias ou secundárias. As fontes primárias estão relacionadas às receitas esperadas e realizadas que derivam da atividade exercida pelo agente tomador de empréstimos. As fontes secundárias são as reservas em dinheiro com as quais o tomador de empréstimos pode contar, ou seja, receitas da concessão de empréstimos, vendas de ativos e a tomada de empréstimos no mercado financeiro.

De acordo com o contexto explorado por Minsky (1986), a economia é afetada por dois tipos de risco, os quais, somados aos outros fatores salientados anteriormente, vão influenciar o preço de oferta e o preço de demanda dos ativos. Um deles é o risco do devedor, que advém da dúvida que o empresário tem de realmente realizar os ganhos esperados de um investimento, e do fato de que, à medida que o volume de investimento aumenta, há um aumento na concentração de ativos da empresa sob a forma de capital físico, elevando o risco do portfólio em função da redução da diversificação e crescimento da imobilização. O outro é o risco do credor, que tem origem em problemas como risco moral ou desapontamento de expectativas, ou seja, agrega o impacto do crescente endividamento para financiar o investimento.

Quanto maior o risco do devedor, menor o preço de demanda dos ativos de capital, visto que, à medida que aumenta a parcela de investimento realizado com financiamento externo ou por meio da venda de ativos, diminuem a margem de segurança e, consequentemente, o preço de demanda. Por outro lado, um aumento no risco do credor traduz-se em aumento do 
preço de oferta. O risco do devedor é subjetivo e nunca aparece em contratos. Já o risco do credor, apesar de subjetivo, aparece em contratos na forma de aumento da taxa de juros, menores prazos de maturidade e exigências de garantias específicas (Minsky, 1975). Considerando que o investimento somente deve ser realizado quando o preço de demanda for igual ou maior que o preço de oferta, o risco do devedor e do credor são determinantes efetivos da evolução do investimento, uma vez que aproximam os dois preços, em função do aumento da exposição ao default.

A hipótese da instabilidade financeira é uma teoria do impacto da dívida sobre a conduta do sistema, incorporando a maneira pela qual essa dívida é validada. Nesse sentido, a concretização dos lucros esperados é determinada pelo investimento, ou seja, a validação das obrigações depende do investimento. ${ }^{9}$ Considerando que as posições das firmas em ativos de capital são financiadas pela combinação de lucros esperados e dívida, há três tipos de financiamento de posições que podem ser identificados na estrutura financeira do sistema: hedge, especulativa e Ponzi.

Uma unidade econômica hedge é aquela em que a quase renda esperada da utilização dos ativos de capital é maior do que os seus compromissos financeiros em todos os períodos. Isso implica que essas unidades são capazes de honrar, com seu fluxo de renda, tanto o pagamento do principal (amortizações) como os juros.

Quando uma unidade econômica é especulativa, seus compromissos financeiros são maiores do que a quase renda esperada para alguns períodos, mesmo que o valor presente dos retornos esperados seja maior que o valor presente dos compromissos de pagamento ao longo do tempo. Essas unidades apresentam um fluxo de renda esperada superior apenas ao pagamento dos juros, sendo necessário obterem refinanciamento para saldar o principal desta. Apresentam uma grande vulnerabilidade em caso de aumento das taxas de juros. Ao mesmo tempo, em caso de taxas de juros flutuantes, qualquer agente que tome recursos emprestados, embora possa estar em uma situação hedge quando contrata o empréstimo, está potencialmente engajado em finanças especulativas.

A unidade econômica Ponzi apresenta uma quase renda esperada insuficiente para cumprir até mesmo com o pagamento do juro da dívida, necessitando, assim, de empréstimos para poder rolar os compromissos de suas 
dívidas. Os agentes que possuem finanças Ponzi esperam que o valor presente de suas receitas líquidas sejam maiores do que seus compromissos ao considerar um prazo mais longo. Tanto a unidade especulativa como a Ponzi necessitam de empréstimos adicionais para realizar seus compromissos. Entretanto, o montante de que a unidade especulativa necessita é menor que a sua dívida vincenda, enquanto a unidade Ponzi amplia suas dívidas.

Sendo possível a mobilidade dos agentes entre as posições financeiras, as unidades podem tanto melhorar quanto piorar de posição. ${ }^{10}$ Conforme Minsky (1992, p. 7-8), a mistura de finanças hedge, especulativa e Ponzi em uma economia é o maior determinante de sua estabilidade. A economia, por meio de seus regimes de financiamento, passa por períodos de estabilidade e por períodos de instabilidade, e em períodos de prosperidade prolongada relações financeiras que se realizam fazem o sistema passar da estabilidade para a instabilidade.

Em Foley (2003), observa-se a formalização dessas posturas, em que a fragilidade financeira surge devido à prática das firmas de utilizarem empréstimos (debt contracts) para financiar a produção. ${ }^{11}$ Nesse tipo de contrato uma determinada firma recebe financiamento de um credor em troca de fluxos de pagamentos fixos de juros e principal (debt service) durante o período do contrato. A falha de uma firma em realizar o pagamento desses fluxos gera a sua bancarrota e, por conseguinte, submete o credor ao risco de não receber os pagamentos do contrato de debt service. Nesse contexto, uma economia está financeiramente frágil, em termos minskyanos, se a bancarrota de uma firma desencadear um conjunto de falências de outras firmas.

Foley (2003) analisa a fragilidade financeira em termos minskyanos a partir do fluxo financeiro das empresas. De forma agregada, a identidade do fluxo de caixa iguala os recursos das firmas oriundos de rendimentos líquidos, $R$, e novos empréstimos, $D$, e os seus usos como fundo de investimento, I, e debt service, $V$.

$$
R+D=I+V
$$

O valor líquido da firma, $W$, é igual à diferença entre o valor dos seus ativos, $A$, e o valor de sua dívida, $B$. Esse valor líquido é aumentado pelo 
investimento, o qual é representado pela mudança nos ativos no tempo, $\dot{A}=I$, e reduzido pelos empréstimos realizados, os quais representam a mudança na dívida durante o período de operação da firma, $\dot{B}=D .{ }^{12}$

$$
\begin{aligned}
& W=A-B \\
& \dot{W}=\dot{A}-\dot{B}=I-D
\end{aligned}
$$

Se uma firma se torna insolvente, $W \leq 0$, então seus credores não serão capazes de reaver o valor do principal de seus empréstimos.

Nesse sentido, conforme a classificação minskyana do estado financeiro das firmas, já discutida, têm-se unidades hedge finance quando $R \geq V+I$, de forma que $D \leq 0 .{ }^{13} \mathrm{Na}$ segunda possibilidade, têm-se unidades especulativas: neste caso, $R \geq V$, mas $R<V+I$, de forma que $D>0$, mas $D<\mathrm{I} .{ }^{14}$ Por fim, têm-se as unidades do tipo Ponzi finance, quando $R<V$, de forma que $D>$ I. $^{15}$

\section{A GERAÇÃO E O DESENCADEAMENTO DA CRISE E OS CICLOS ECONÔMICOS}

Conforme a hipótese da instabilidade financeira, a ausência de dificuldades financeiras sérias sobre um período substancial conduz ao desenvolvimento de uma economia eufórica, na qual o aumento do financiamento de curto prazo de posições de longo prazo torna-se um caminho normal.

Diante da vigência de um nível de demanda efetiva e de lucros que, por um determinado período de tempo, valide as decisões e os passivos assumidos no momento anterior, o estado de expectativas a longo prazo acaba sendo afetado. Conforme Minsky (1975), durante um boom a estimação dos riscos do credor e do devedor tende a se tornar imprudentemente baixa. Os banqueiros vivem no mesmo clima de expectativas que os acionistas e gerentes. A extensão em que a alavancagem se realiza depende, além das expectativas das firmas que investem, da disposição dos banqueiros em emprestar e dos acionistas em segurar ações alavancadas.

O aumento no volume do investimento acaba por gerar um nível de lucro superior ao que fora antecipado, alterando favoravelmente, em um primeiro momento, a relação entre o financiamento interno e o externo, ainda 
que este tenha aumentado. ${ }^{16}$ Como o nível e a tendência dos lucros entram na determinação do preço dos ativos de capital, o preço de demanda tende a aumentar, dados o aumento da quase renda esperada e o aumento do preço que será pago no mercado por uma série temporal de quase rendas esperadas. Enquanto isso, o preço de oferta tende a cair, dada a queda da preferência pela liquidez e do custo financeiro. Esses fatos contribuem para aumentar o volume de investimento, e essa expansão proporciona um maior endividamento, fazendo com que as unidades assumam posições cada vez mais especulativas. ${ }^{17}$

Os banqueiros, estimulados pelo sucesso dos empreendimentos e pelo ambiente de tranquilidade que se apresenta, reavaliam positivamente suas expectativas e passam a aceitar níveis maiores de endividamento. Assim, para fazer frente a tal situação, considerando uma determinada quantidade, de reservas, criam novas práticas financeiras e novas instituições. Durante o boom, as inovações financeiras se propagam e permitem a sustentação do investimento e do preço dos ativos de capital. ${ }^{18}$

Nessa visão, Minsky (1975 e 1986) aponta a atividade bancária assumindo um papel essencial na desestabilização das relações econômicas, ou seja, o sistema bancário surge como o “desestabilizador endógeno”.

A despeito da importância da atividade bancária apontada por Minsky, observa-se atualmente que a evolução do processo de desintermediação e sofisticação financeira decorrente da emergência de fundos de pensão, grandes corretoras de investimento, fundos/clubes de investimento, fundos mútuos, departamentos de negócios bancários para aplicação em ativos (como ações, derivativos, dentre outros), tem também o poder de desestabilizar a economia. Além disso, em diversos mercados, investidores institucionais, como sociedades seguradoras, sociedades de capitalização e fundos externos de investimento, têm assumido grande papel na conformação de mudanças financeiras estruturais.

Segundo Carvalho et al. (2000) e Lourenço (2006), no caso da economia estadunidense, em particular, um conjunto de modificações estruturais ainda inclui o processo de securitização de dívidas, a ampliação dos mercados derivativos, a segmentação bancária e uma tendência cada vez maior de desregulamentação e liberalização financeiras encabeçada, na maioria das vezes, por representantes diretos dos grandes investidores institucionais. ${ }^{19}$ 
Ao longo de um boom econômico, firmas, acionistas e instituições financeiras assumem posições mais arriscadas. ${ }^{20}$ As firmas engajam-se em um volume maior de financiamento de dívidas, os acionistas e as firmas diminuem ativos líquidos em relação à dívida e os bancos aumentam seus empréstimos. As unidades, tanto produtivas como financeiras, passam a operar com estruturas obrigacionais em que o fluxo de dinheiro necessário para a realização dos compromissos se torna maior que as receitas. Nesse sentido, de acordo com Kregel (2007, p. 7):

(...) stability in the economic system generates behaviors that produce fragility, and increasing fragility makes the system more prone to an unstable response to change in financial or other conditions that are relevant to the return on investment projects. Minsky expressed this idea in terms of a declining "margin" or "cushion" of safety in financial transactions and an increase in financial leverage that he called layering.

A instabilidade de um regime com predominância de estruturas de financiamento especulativas ou Ponzi está relacionada, em grande medida, ao impacto das taxas de juros, que tendem a se elevar durante o boom. ${ }^{21}$ Essa elevação tem efeitos opostos sobre o preço de demanda e o preço de oferta, diminuindo a diferença entre eles, podendo mesmo chegar a uma reversão, o que ocasiona uma interrupção dos investimentos em nível macro. A queda do investimento provoca mais queda nos lucros, causando dificuldades para pagar as dívidas acumuladas anteriormente.

Quando aumenta o perigo das estruturas obrigacionais, a demanda especulativa por dinheiro aumenta e as empresas endividadas e instituições financeiras tentam vender ativos para pagar dívidas. O nível de preços de demanda dos ativos de capital e financeiros diminui em relação ao custo de produção dos bens de investimento, e nesse momento é identificada uma crise.

Assim, verifica-se que, durante o período de boom, ocorre uma redução da estabilidade do sistema, o que se explica pela formação de uma estrutura de dívida, cuja validação não é permitida pelo fluxo de renda das empresas. Isso torna a economia financeiramente frágil e propensa a crises. No entanto, as condições para a precipitação da crise somente surgem na presença de fragilidade financeira. ${ }^{22}$ 
A crise financeira gera uma indisposição crescente em financiar o investimento, o que leva, consequentemente, a uma queda nos gastos com investimento. Essa redução, por sua vez, afeta negativamente os lucros, o que aumenta a dificuldade em pagar os compromissos da dívida contraída anteriormente (Wolfson, 2002). O default sobre o pagamento da dívida promove um declínio da demanda agregada, com consequente redução de preços, aumento no valor real dos compromissos de pagamento da dívida, acelerando a interação de espiral para baixo dos preços. Quando a economia emerge de uma recessão que segue a crise financeira, sua estrutura está mais robusta do que quando a crise ocorreu. ${ }^{23}$ Constata-se, assim, que a fragilidade financeira decorre do funcionamento normal da economia.

Então, na concepção minskyana, a economia passa por períodos de tranquilidade, os quais são rompidos por booms de investimento, aceleração inflacionária, crises monetárias e financeiras e deflações de dívidas. A instabilidade emerge quando um período de crescimento relativamente tranquilo é transformado em boom especulativo. O boom especulativo tende a ser seguido pelo pânico, deflações de dívidas, depressões profundas e, na sequência, pela recuperação. Lourenço (2006) propõe que o ciclo minskyano deva ser explorado como uma sucessão de estados transitórios, quais sejam, boom, crise, deflação, estagnação, expansão e recuperação, enfatizando-se a transição, sucessão e recorrência desses estados, e não sua regularidade temporal ou simetria, mesmo porque, segundo ele, Minsky sugere a assimetria, no sentido de que a recuperação tende a ser mais lenta que a irrupção da crise. ${ }^{24}$ Entretanto, as fases do ciclo são de menor importância, conforme Minsky (1986), para analisar a instabilidade do que o desenvolvimento que ocorre no período de crescimento sustentado e que conduz à fragilidade e à instabilidade financeira.

Intervenções podem abortar a crise por meio do refinanciamento das empresas ou sustentando os lucros por meio do deficit fiscal. Assim, a atuação de um Big Government evitaria depressões. Outra forma de evitar ou diminuir a fragilidade financeira das unidades é por meio do Big Bank, que atua como emprestador em última instância, agindo sobre a estrutura de ativos e passivos. ${ }^{25}$

Diferentemente do Big Government, o Big Bank deve agir antes de a crise eclodir. Ambos são de grande importância para Minsky e têm como objeti- 
vo a estabilização da economia, isto é, evitar ou diminuir a fragilização crescente dos agentes econômicos. Contudo, é preciso destacar, conforme Minsky (1986), que tanto as ações do Big Government como as do Big Bank, que abortam as consequências de estruturas financeiras frágeis, conduzem para a inflação, que possibilita às firmas e instituições financeiras cumprir com compromissos que não poderiam, em um contexto de preços estáveis.

Conforme Wolfson (2002), na visão minskyana, operações realizadas pelo emprestador de última instância não são suficientes para evitar o reaparecimento de deflações de dívidas e crises financeiras. Nesse sentido, fazse necessário que os policymakers controlem a criação das inovações financeiras, isto é, caso a intervenção do emprestador de última instância não ocorra acompanhada por regulações e reformas que restrinjam as práticas no mercado financeiro, o que acaba por se gerar é um estágio de financiamento com expansão inflacionária, caso os banqueiros e as demais instituições financeiras tenham se recuperado do choque transitório da crise.

A crise financeira das unidades e a crise da economia são explicadas, então, pela interrupção no fluxo do financiamento que ocorre em função da desconfiança dos emprestadores com relação à validação do crédito concedido. No entanto, conforme Lourenço (2006), a interpretação minskyana das flutuações das economias capitalistas sofisticadas do ponto de vista financeiro não postula a inexistência de choques exógenos, nem mesmo desconsidera seus impactos na geração de uma crise. Porém, tais choques não são necessários para formalizar tais flutuações. Quer dizer, a crise financeira até pode ser desencadeada por decisões de política econômica equivocadas, mas nesse caso o país já deve estar inserido em contexto de fragilidade financeira, englobando, além do sistema bancário, os demais agentes econômicos, como fundos de investimento e tomadores de recursos. ${ }^{26}$

No que diz respeito à endogeneidade do processo e à dinâmica cíclica na economia, Dymski e Pollin (1992) sugerem uma interpretação mista. ${ }^{27}$ Se, por um lado, a fragilização da estrutura financeira dos agentes econômicos é completamente endógena, a partir da adoção de posturas financeiras mais alavancadas e especulativas, por outro, a reversão da tendência da economia se desencadeia a partir de um choque exógeno, como, por exemplo, a partir das mudanças de taxa de juros da autoridade monetária, ou demais tipos de política econômica, como aumento do custo das operações de redesconto. ${ }^{28}$ 
Isso posto, observa-se que as modificações sugeridas a partir do arcabouço original de Minsky implicam que as crises à la Minsky podem surgir sem ter ocorrido um ciclo econômico tipicamente sugerido por esse autor. Além disso, Dymski (2004) destaca que essas crises dependem essencialmente das particularidades de momento histórico e lugar, que são o pano de fundo dos fluxos financeiros internacionais, bem como da maior sofisticação e inovação dos sistemas financeiros. ${ }^{29}$

\section{A INSTABILIDADE FINANCEIRA ESTADUNIDENSE: ALGUNS FATOS ESTILIZADOS À LUZ DA TEORIA}

Em 2007, observou-se uma crise de liquidez no mercado global que se iniciou com problemas na oferta de crédito no mercado imobiliário norteamericano (mercado subprime), tendo gerado, em especial, fortes perdas nas bolsas de valores no mês de agosto de 2007, além de um grande número de anúncio de falências individuais, inadimplências e anúncios de prejuízos bilionários em bancos estadunidenses e europeus. ${ }^{30}$ Nesse contexto, o arcabouço teórico de Hyman P. Minsky e demais contribuições dessa linha de pesquisa, a partir da análise e evolução das estruturas financeiras dos agentes econômicos, oferecem grande substância teórica para explicar a dinâmica dos acontecimentos recentes no interior daquela economia.

Os chamados mercados "subprime" e "Alt-A loans" no setor hipotecário dos Estados Unidos são gerados a partir de empréstimos com tomadores que podem oferecer menos garantias reais de pagamentos, por isso embutem maior risco de crédito e, por consequência, têm juros maiores em relação à categoria prime, o que os torna mais atrativos para gestores de fundos

em busca de retornos superiores à média de mercado. ${ }^{31} \mathrm{O}$ volume global de operações desse mercado é de US\$ 1,5 trilhão, com uma fatia de US\$ 250 bilhões de clientes inadimplentes. ${ }^{32}$ Mishkin (2007, p. 13), em consonância com o trabalho de Aoki, Proudman e Vlieghe (2002), aponta que:

(...) with an advanced financial infrastructure, improvements in information technology have led to financial innovations that have been making mortgage markets more efficient. Down-payment requirements have been falling, along with refinancing costs, and the use of credit scoring has widened access to housing loans (...) these developments suggest that the cost of mortgage equity 
withdrawals in the United States has declined over time, thereby potentially increasing the responsiveness of consumer spending to changes in house prices.

Segundo Papadimitriou, Hannsgen e Zezza (2007), esse tipo de empréstimo cresceu cinco vezes no período compreendido entre 2001 e 2005 . Além disso, uma parcela considerável desses empréstimos foi utilizada para a aquisição de bens de consumo, os quais tiveram grande peso nas taxas de crescimento de economia estadunidense, a partir de sua maior participação no consumo agregado. ${ }^{33}$ Nesse sentido:

(...) Another way to think about the effect of higher home equity is to consider its ability to relax credit constraints. When house prices rise, homeowners have additional collateral against which they can borrow, a phenomenon that is referred to as mortgage equity withdrawal (also called home equity extraction). Mortgage equity withdrawals provide a route through which rising house prices can stimulate consumption spending. Some economists see this channel as playing a very important direct role in determining spending (Mishkin, 2007, p. 12).

Com a sofisticação do mercado financeiro estadunidense, operações em que créditos são gerados em um determinado mercado podem ser convertidas em ativos (como títulos securitizados) que vão render juros para investidores alhures. Kregel (2007, p. 11) ressalta que, a partir de 1999:

(...) Gramm-Leach-Bliley (Financial Services Modernization) Act, which allowed the creation of bank-holding companies to carry out virtually all types of financial activities. At the same time, the extensive application of Basel minimum capital standards in 2004 encouraged banks to continue to increase their fee and commission incomes by moving lending to unrelated affiliates, and off their balance sheets. This system has produced a new form of bank operations now known as "originate and distribute," in which the bank seeks to maximize its fee and commission income from originating assets, managing those assets in off balance-sheet affiliate structures, underwriting the primary distribution of securities collateralized with those assets, and servicing them. Under this system, the banker has no interest in credit evaluation, since the interest and principal on the loans originated will be repaid to the final buyers of the collateralized assets. (...) The bank is only interested in its ability to sell the asset it has originated in order to earn a fee or commission, not to hold the asset in its loan book for a return determined by the net interest margin.

Em consonância com o exposto, Calza, Monacelli e Stracca (2007) realizaram um estudo em que observaram que a correlação da taxa de cresci- 
mento do consumo em relação ao aumento do preço dos imóveis é maior em economias cujo sistema financeiro hipotecário (mortgage finance system) é mais desenvolvido.

De acordo com Shiller (2006), os preços de imóveis nos Estados Unidos estavam razoavelmente baixos em termos reais de 1980 a 1997. Contudo, desde 1998, eles aumentaram a uma taxa de 6\% a.a. em termos agregados. Essa aceleração dos preços reflete uma taxa de crescimento maior do que a renda da população residente na maioria dos estados norte-americanos. Nesse sentido, observou-se um descompasso entre a taxa de crescimento da renda média da população e o preço dos imóveis. Nesse cenário, a demanda de mais imóveis só foi possível com o aumento de crédito destinado a esse mercado e a flexibilização das exigências para as hipotecas.

Em outro estudo, Davis, Ortalo-Magné e Rupert (2007) apontaram que o boom imobiliário vivenciado nos Estados Unidos pode ser explicado por dois argumentos. O primeiro deles está relacionado com os preços das áreas de construção, os quais estão aumentando em termos reais desde 1950, com uma expansão maior no período de 1998 a 2006. O segundo ponto está relacionado a um relaxamento das restrições de crédito no mercado, como se observa também em Shiller (2006).

Qualquer tipo de mudança no setor bancário de uma economia que aumente a acessibilidade de compra de um ativo, como um imóvel, pode ter grandes impactos sobre o preço deste e sobre sua volatilidade ao longo do tempo, como ficou evidenciado nas seções 1 e 2 do presente trabalho. Esse fato foi observado na economia norte-americana. Com o crescimento do mercado de hipotecas, chegou-se a ter $70 \%$ de "prime" (primeira linha), 20\% de "subprime" (segunda linha) e 10\% de crédito "alternativo" (Alt-A loans) - aquele que não tem qualquer tipo de avaliação. Esse crescimento fez com que se valorizasse o preço médio dos imóveis de tomadores de risco até meados de 2006. Contudo, alguns imóveis não cobrem suas hipotecas e não servem mais de garantias aos bancos, dada a sua queda de valor até fins de 2008, de acordo com dados do Federal Reserve (www.federalreserve.org).

No bojo desta discussão, observa-se uma situação de fragilidade financeira por parte dos agentes econômicos, como bancos e tomadores de recursos no mercado financeiro. 
Como evidenciado nas seções 1 e 2, a partir de trabalhos de Minsky, temse um importante arcabouço das situações em que uma economia passa por períodos desestabilizadores a depender da estrutura financeira de seus agentes econômicos. Nesse sentido, a tendência das posições financeiras dos agentes econômicos, ao optarem por maior endividamento em períodos de prosperidade (aumentando a relação de dívidas e ativos), é fundamental para a maior suscetibilidade de crises econômicas.

No caso da economia dos Estados Unidos, no período de crescimento econômico, a partir de 2001, as exigências para concessão de crédito a consumidores foram rebaixadas e os agentes econômicos incentivados a permutar empréstimos com taxas fixas (6\% a.a.) por juros variáveis para refinanciar as hipotecas em condições inicialmente vantajosas, gastando parte da diferença em bens duráveis e semiduráveis. Em alguns casos, os mortgage debt contracts proporcionavam prestações muito baixas nos primeiros anos. Segundo constatação de Stiglitz (2006), tais prestações eram menores até o valor dos juros devidos, de maneira que não ocorria amortização e a dívida aumentava em vez de diminuir, resultando em prestações mais dispendiosas nos anos seguintes. Nesse caso, a fragilidade financeira se estende das empresas para os tomadores de recursos e demais agentes econômicos envolvidos no processo de canalização de crédito para o setor imobiliário.

Diante do exposto percebem-se, aqui, vários comportamentos originalmente descritos por Minsky. Primeiramente, a ausência de dificuldades financeiras sérias por um período substancial conduziu ao desenvolvimento de uma economia eufórica no mercado imobiliário dos Estados Unidos, com um aumento nas facilidades para se adquirir empréstimos, bem como aumento no volume destes e nos preços dos ativos. Logo, a economia passou de um período de tranquilidade para um período de boom especulativo, momento em que, segundo a visão minskyana, a instabilidade emerge. Ao mesmo tempo, salienta-se, também, que conforme discutido anteriormente, na visão minskyana, um agente econômico que contrate empréstimos à taxa de juros flutuantes - o que passou a acontecer nos Estados Unidos mesmo encontrando-se em uma posição financeira hedge, está potencialmente engajado em finanças especulativas, pois qualquer alteração do cenário econômico, que promova um aumento nas taxas de juros pode provocar fragilidade. 
Em condição de franco crescimento econômico, ${ }^{34}$ na qual os erros na estimativa de retornos futuros diminuem, os bancos tomaram posições mais arriscadas e mais otimistas em relação ao fluxo futuro de renda dos tomadores de recursos. Nesse contexto, Banerjee (1992) estabelece que "fazer o que todo mundo faz" é uma atitude racional por parte dos agentes econômicos em um contexto em que acreditam que os demais agentes podem ter mais informações do que a possuída pelos primeiros. Sendo assim, esse canal de crédito (subprime e Alt-A) se manteve em franca expansão. ${ }^{35}$

De acordo com uma análise de dados da Bear Sterns, de 2004 a 2006, 8,7 milhões de clientes de segunda linha contraíram hipotecas, diante de 6,5 milhões nos sete anos anteriores. Nesse mesmo período de análise, foram contraídas dívidas hipotecárias a juros flutuantes no valor de US\$2,28 trilhões.

Quando a taxa de juros do mercado estadunidense se ajustou no período de 2004 a 2007 (a Federal Fund Rate saiu de 1,0\% a.a. em 2004 para mais de $5 \%$ a.a. em 2006), muitos agentes econômicos tomadores de recursos possuíam estruturas financeiras superiores ao valor de seus ativos, prestações superiores à sua renda e baixo grau de poupança.

\section{A TEORIA DA RENDA PERMANENTE,} FLUXO DE RENDA E FRAGILIDADE FINANCEIRA

No caso do setor imobiliário norte-americano, observam-se claramente alguns condicionantes para a existência de uma situação especulativa e Ponzi para alguns dos tomadores de recursos. Isso se verifica, por exemplo, nas referidas mudanças da análise de crédito que permitiram o crescimento da categoria "subprime" e "Alt- $A$ " e no aumento menos que proporcional do fluxo de renda dos tomadores de recursos em relação aos imóveis adquiridos, de acordo com o que foi evidenciado na seção 3.

Esse crescimento do preço dos imóveis contribuiu para o aumento da riqueza de seus proprietários e deu suporte a um aumento contínuo dos gastos em consumo, como exporemos adiante. Esse aspecto tem suporte em Friedman (1957) com a teoria da renda permanente, segundo a qual as famílias desejam nivelar o consumo ao longo do tempo, isto é, seu consumo não deve ser influenciado pelas variações puramente transitórias dos seus 
rendimentos (como os fluxos de salários). As famílias pautam suas decisões de consumo com base na sua "renda permanente", ou seja, o nível constante de renda que lhes proporciona a mesma restrição orçamentária intertemporal que elas teriam no caso de um fluxo de renda flutuante. ${ }^{36}$

A valorização dos imóveis, combinada com um ambiente de baixas taxas de juros e inovações financeiras, fez com que aumentasse a capacidade de seus proprietários de se dirigirem ao sistema bancário e obter mais recursos que não eram gastos com ativos imobiliários. ${ }^{37}$ Nesse sentido, Case, Quigley e Shiller (2005) encontraram que a elasticidade de gasto com consumo relacionado à riqueza imobiliária dos agentes econômicos está entre 11 e 17\%, enquanto é de $2 \%$ para a mesma relação com o mercado acionário. Bayoumi e Edison (2003) encontraram evidências de que a propensão marginal a consumir para cada dólar é de 7 centavos para o ativo imóvel e de 4,50 centavos para a mesma propensão para o mercado acionário. Além disso, Carroll, Otsuka e Slacalek (2006), utilizando-se de séries históricas dos Estados Unidos, estimaram que a propensão marginal a consumir de longo prazo para cada unidade de dólar é de nove centavos para riqueza de imóveis e de quatro centavos para todos os demais tipos de riqueza (nonhousing wealth).

Com o aumento do descasamento entre o fluxo de renda e o serviço de pagamento da dívida imobiliária (mortgage debts) - que caracteriza boa parte das posições especulativas e Ponzi do mercado imobiliário —, verifica-se que a parcela de hipotecas que entrou em processo de execução subiu no segundo trimestre de 2007 para 0,65\%, sendo esse o patamar mais alto em 55 anos de acordo com a MBA (Associação Americana de Bancos de Hipoteca). ${ }^{38}$

Nesse contexto, a falha de um agente econômico em realizar o pagamento desses fluxos da dívida (debt service) gera a inadimplência individual e, por conseguinte, submete o credor ao risco de não receber os pagamentos do contrato, bem como gera a possibilidade de execução da hipoteca. Isso obviamente reduz, de acordo com a visão minskyana, a disposição dos emprestadores em conceder novos empréstimos. Como se pode perceber, o setor imobiliário norte-americano está financeiramente frágil em termos minskyanos.

Essa estrutura econômica de fragilidade financeira fez com que o Federal Reserve, bem como outras autoridades reguladoras do setor bancário, 
divulgasse recentemente (final do segundo semestre de 2007) um manual para as financiadoras para que negociem com as pessoas que pegaram empréstimos para adquirir uma casa e agora correm o risco de perdê-la por falta de pagamento, especialmente no setor de crédito "subprime". ${ }^{9}$ Além disso, está ocorrendo refinanciamento de parte dos empréstimos garantidos pelo governo, ações que evitam execução da dívida e alívio na tributação de quem refinanciar o que deve (em certo grau, uma ação do tipo Big Government).

O FED também manteve sua política de atuação no mercado financeiro norte-americano como forma de elevar a liquidez do sistema financeiro e evitar o aumento exagerado das taxas de juros, o que geraria mais restrições no mercado de crédito para os tomadores de recursos. Ou seja, quando a fragilidade tornou-se exposta e a crise foi desencadeada, houve intervenção do FED atuando como emprestador de última instância. Um dos efeitos colaterais dessa ação do FED como Big Banké sua influência sobre o mercado cambial. O aumento dessa liquidez incrementa a oferta relativa de dólares, o que, por sua vez, somado aos deficits em transações correntes dos Estados Unidos, faz com que o dólar se desvalorize no mercado mundial.

Um dos fatores que geram expectativas negativas no mercado financeiro internacional está relacionado à incerteza em relação à carteira de aplicações de grandes bancos norte-americanos e a que grau foram contaminados por essa crise no setor imobiliário norte-americano. Além disso, um fator complicador apontado por Papadimitriou, Hannsgen e Zezza (2007) é que apenas uma de cada cinco hipotecas americanas está em mão de bancos que emprestaram recursos. O restante está lastreado em outros ativos financeiros, sendo US $\$ 120$ bilhões nos bancos comerciais europeus.

Como foi evidenciado a partir de diversos estudos, os desenvolvimentos no mercado imobiliário dos Estados Unidos têm impactos positivos sobre o nível de atividade econômica daquele país, a partir, principalmente, dos gastos com consumo e dos investimentos das empresas. Mesmo os agentes econômicos que não são "subprime” terão de diminuir seu nível de consumo, uma vez que o nível de queda dos seus ativos foi da ordem de 20\% em 2007, reduzindo, assim, as garantias de refinanciamento. Em relação aos investimentos, a queda de 1,84 milhão de unidades de imóveis em janeiro de 2006 para o nível de 1,15 milhão de unidades, aproximadamente, até agosto de 
2007 fez com que a queda do nível do investimento em residências diminuísse o nível de crescimento em 1 ponto percentual no período de quatro trimestres (Mishkin, 2007).

Além dos impactos sobre o nível de consumo e investimento, o mercado imobiliário tem grande efeito sobre o canal de crédito da economia, meio pelo qual diversos agentes econômicos de uma maneira geral financiam seus investimentos. Um aumento do risco de empréstimos e financiamentos pode elevar a taxa de juros dos futuros contratos no mercado de crédito. Uma vez que esse canal de crédito também afeta o nível de consumo e investimento, a expectativa de crescimento econômico é diminuída. ${ }^{40}$ Esse comportamento também é descrito na visão minskyana, ou seja, a crise financeira gera uma indisposição crescente em financiar o investimento, o que leva, consequentemente, a uma queda nos gastos com investimento. Essa redução, por sua vez, afeta negativamente os lucros, aumentando a dificuldade em pagar os compromissos da dívida contraída anteriormente. Na sequência, o default sobre o pagamento da dívida promove um declínio da demanda agregada. ${ }^{41}$

\section{A CRISE FINANCEIRA MINSKYANA EM UMA ECONOMIA ABERTA}

Na figura 1, ao considerar-se inicialmente uma economia fechada (ou seja, $S e=0, T C=0$ e $T K=0),{ }^{42}$ a evolução dos balanços econômicos das empresas é acompanhada por um padrão cíclico no relacionamento entre os preços de mercado $(\mathrm{Pk})$ e custos de produção $(\mathrm{Pi}) .{ }^{43}$

De acordo com a visão de Minsky, à medida que avançam os períodos de expansão (primeira região retangular da figura 1), surge uma bolha de ativos ( $\mathrm{Pk}$ tem um crescimento muito superior a Pi). Essa forma de crescimento acelerado diminui a capacidade industrial (aumento de NUC - Nível de Utilização da Capacidade Produtiva) e obriga as empresas a contraírem dívidas para ampliar sua capacidade produtiva. Como foi demonstrado na primeira seção, o valor líquido da firma, $W$, é igual à diferença entre o valor dos seus ativos, $A$, e o valor de sua dívida, $B$. Esse valor líquido é aumentado pelo investimento, o qual é representado pela mudança nos ativos no tempo, $\dot{A}=I$, e reduzido pelos empréstimos realizados, os quais representam a mudança na dívida durante o período de operação da firma, $\dot{B}=D$. 
Nesse caso, muitas unidades se tornam unidades especulativas - se $R \geq$ $V$, mas $R<V+I$, de forma que $D \geq 0$, mas $D<I$ - e Ponzi - se neste caso $R<V$, de forma que $D>I .{ }^{44}$ Durante certo tempo, expectativas positivas e pressão concorrencial aumentam de forma substancial a relação dívida/receita e $\mathrm{Pk} / \mathrm{Pi}$ (a segunda e terceira parte da figura 1). Quando ocorre a dominância de situações Ponzi, em que se observa a incapacidade de atender às obrigações contraídas, geram-se inadimplência e bancarrotas (com deflação das dívidas) e a relação Pk/Pi cai (queda do preço do ativo). Além disso, aumentos dos custos de financiamento $\left(i_{1}>i_{0}\right)$ contribuem para a criação de mais unidades especulativas e Ponzi, bem como reduzem o ritmo de crescimento do produto, podendo, inclusive, ser observada uma recessão (segunda e terceira região retangular).

Dada a maior sofisticação do sistema financeiro estadunidense, surge a necessidade de se introduzir adaptações nessa interpretação do ciclo e crise. Nesse caso, observa-se que a relação Pm/Pi' (preço de mercado dos imóveis em relação ao custo de utilização dos ativos de capital para sua construção) subiu muito substancialmente durante um razoável período de tempo, como foi evidenciado, em um ambiente de baixa taxa de juros $\left(i_{0}\right)$ e crédito barato (primeira região retangular). Dessa forma, a relação dívida/fluxo de renda cresceu sobremaneira em relação aos tomadores de recursos finais (famílias) em um ambiente em que se acreditava na permanência da manutenção das taxas de juros em patamares baixos. Além disso, boa parte do investimento em ativos imóveis foi financiada com recursos do exterior $($ Se $>0$ e TK $>0) .{ }^{45}$ Quando as taxas de juros subiram para $i_{1}$ (choque exógeno - na segunda região retangular), muitos tomadores de recursos se encontraram em uma situação Ponzi ou especulativa, de forma que tiveram de se desfazer de seus ativos imóveis (terceira região da figura), contribuindo para a queda da relação ( $\left.\mathrm{Pm} / \mathrm{Pi}^{\prime}\right)$ e o surgimento de grande instabilidade no sistema bancário, que concedia crédito imobiliário no mercado subprime, e, por consequência, em outros mercados. Como parte do ganho desses ativos, no caso da economia estadunidense, era gasta em bens de consumo duráveis e semiduráveis, o NUC apresentou declínio (figura 1).

Na prática, a transição da região 2 para a região 3 se dá a partir de um choque exógeno da taxa de juros, em que pese a lógica endógena do processo de mudança dos balanços econômicos e financeiros das famílias (no caso 
Figura 1: Dinâmica de uma crise financeira a partir do arcabouço teórico minskyano em uma economia aberta

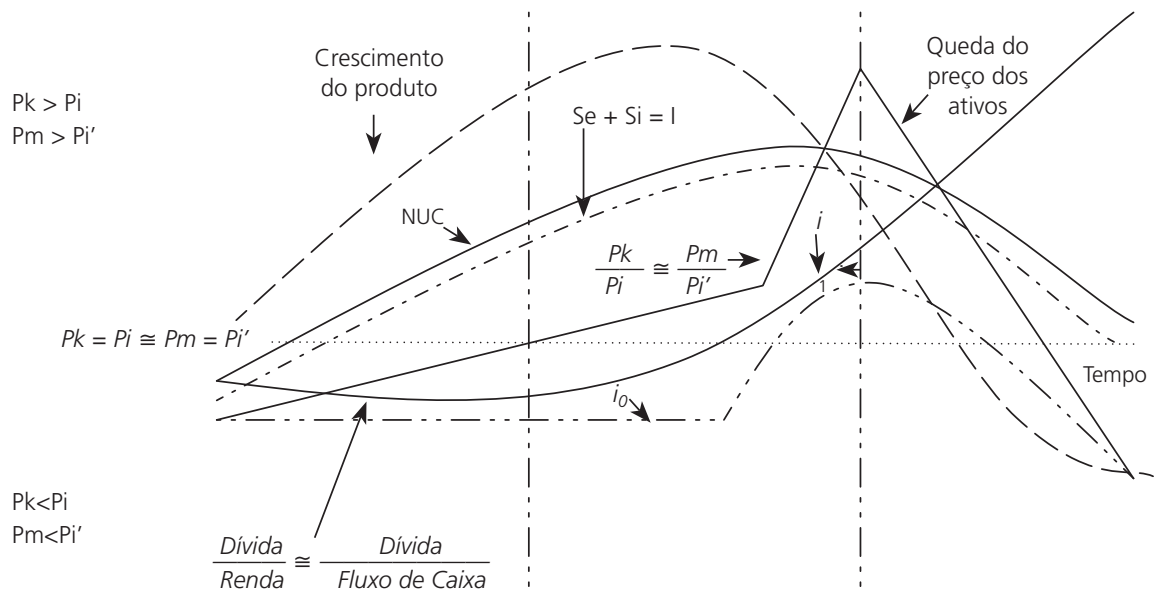

Fonte: Adaptação analítica para uma economia aberta a partir da versão de Dymski (2004, p. 438).

da economia estadunidense, em especial). ${ }^{46}$ Ao mesmo tempo, as condições de $\mathrm{Pk}>\mathrm{Pi}$ e $\mathrm{Pm}>\mathrm{Pi}$ não determinam per se a trajetória do investimento, pois essa dinâmica depende: a) da renda esperada do uso do ativo de capital e b) do custo do investimento, o qual depende, por sua vez, dos canais de financiamento (mormente crédito bancário) da economia. Como esse custo torna-se mais elevado e os ativos apresentam queda de seu preço, o crescimento do produto é comprometido. Os mecanismos contracíclicos dependem da ação do Big Bank e do Big Governement.

\section{CONSIDERAÇÕES FINAIS}

Durante a fase de crescimento mais acelerado da economia estadunidense (2002-2006), as estimativas dos riscos dos credores e dos devedores do mercado imobiliário tenderam a ser imprudentemente baixas. Estimulados pelo crescimento do setor imobiliário no período, parte dos recursos do mercado de crédito bancário foi canalizada para compra de imóveis com alta valorização em um curto período de tempo.

Em um ambiente de incerteza, a partir do momento em que existe algum tipo de convenção otimista no mercado a respeito do futuro, os bancos con- 
cedem mais empréstimos e financiamentos para tomadores de recursos mais arriscados, acabando por diminuir a margem de segurança das operações. Nesse contexto, abre-se a possibilidade de concentração de riscos na economia. No caso da economia estadunidense, essa concentração de risco ocorreu no setor imobiliário com empréstimos altamente alavancados (categoria subprime e Alt-A).

Como no período analisado o fluxo de renda média cresceu menos do que o serviço de pagamento da dívida imobiliária (processo endógeno de fragilização financeira), vários agentes econômicos se encontraram em uma situação financeira especulativa e Ponzi, principalmente depois do aumento da taxa de juros básica da economia (choque exógeno). Nesse sentido, esses agentes ou venderam seus ativos ou entraram em processo de execução judicial. Esse processo fez com que o preço dos imóveis caísse de forma vertiginosa.

A queda no preço dos imóveis tende a gerar impactos negativos sobre o nível de consumo e investimento na economia. Porém, além disso, o mercado imobiliário tende a ter um grande efeito sobre o canal de crédito da economia, meio pelo qual diversos agentes econômicos, de maneira geral, financiam seu investimentos. Um aumento do risco de empréstimos e financiamentos pode elevar a taxa de juros dos futuros contratos no mercado de crédito. Uma vez que esse canal de crédito também afeta o nível de consumo e investimento, a expectativa de crescimento econômico é diminuída. Na sequência, o default sobre o pagamento da dívida promove um declínio da demanda agregada, gerando menores contratações no mercado de trabalho.

\section{NOTAS}

1. O modelo básico da teoria de Hyman P. Minsky (1919-1996) focou sua análise em uma economia fechada. Uma das razões para esse tratamento está relacionada ao fato de que, para ele, os Estados Unidos eram um caso paradigmático de grande economia com mercados financeiros amadurecidos em seus primeiros estudos. Nesse sentido, serão abordados modelos de tradição miskyana, mas que tratam de uma economia aberta.

2. A ideia básica de ciclo em Kalecki pode ser encontrada no livro Crescimento e ciclo das economias capitalistas (1990), o qual apresenta ensaios originalmente publicados por esse importante economista polonês entre 1933 e 1971.

3. Os motivos que fazem o peso da dívida dos agentes econômicos aumentarem serão tratados mais adiante. 
4. Conforme Minsky, "the present money pays for resources that go into the production of investment output, whereas the future money is the 'profits' wich will accrue to the capital asset owning firms (as the capital assets are used in the production)" (1992, p. 2).

5. Nesse sentido, em concordância com esses primeiros trabalhos: “(...)The first theorem of the financial instability hypothesis is that the economy has financing regimes under which it is stable, and financing regimes in which it is unstable. The second theorem of the financial instability hypothesis is that over periods of prolonged prosperity, the economy transits from financial relations that make for a stable system to financial relations that make for an unstable system. In particular, over a protracted period of good times, capitalist economies tend to move to a financial structure in which there is a large weight to units engaged in speculative and Ponzi finance. Furthermore, if an economy is in an inflationary state, and the authorities attempt to exorcise inflation by monetary constraint, then speculative units will become Ponzi units and the net worth of previously Ponzi units will quickly evaporate. Consequently, units with cash flow shortfalls will be forced to try to make positions by selling out positions. This is likely to lead to a collapse of asset values" (Minsky, 1992, p. 7-8).

6. Minsky afirma que, da mesma forma que os ativos de capital, os ativos financeiros também possuem preço de demanda e preço de oferta.

7. Segundo Minsky (1986), a quase renda é a diferença entre a receita total da venda da produção produzida com a ajuda de ativos de capital e os custos determinados tecnicamente, associados com a produção. É um conceito de lucro bruto esperado, depois de deduzidos os impostos.

8. Conforme Minsky (1986), o preço do ativo de capital aumenta em função do aumento da quantidade de dinheiro, porque, quando isso acontece, diminui o valor de segurança existente no dinheiro. Como o preço do dinheiro é sempre o mesmo, isso implica que o preço dos ativos de capital que geram renda aumente. Entretanto, em casos em que a demanda por liquidez é infinitamente elástica, o preço dos ativos de capital pode cair quando aumenta a oferta de dinheiro. Já em casos de expectativas inflacionárias, o preço dos ativos de capital pode aumentar de forma mais rápida que o aumento na oferta de dinheiro, pois os agentes "correm do dinheiro".

9. Em um modelo com dois setores, em que trabalhadores consomem todo o seu salário e capitalistas poupam todo o seu lucro, apenas uma variação no nível de investimento pode perturbar um determinado nível de lucros. Quando o modelo é ampliado, o investimento continua sendo o principal determinante dos lucros. Contudo, existem outros determinantes, como o orçamento do governo, o comportamento do consumo e a trajetória dos salários nominais (Minsky, 1986).

10. De acordo com Minsky (1986), um arranjo financeiro especulativo pode ser transformado em Ponzi por meio do aumento nos juros ou outros custos ou da queda na renda. Por outro lado, se os ganhos são maiores, ou os custos, especialmente os juros, caem, as unidades financeiras Ponzi podem ser transformadas em especulativas. Da mesma forma, unidades hedge podem tornar-se especulativas e unidades especulativas podem tornar-se hedge.

11. A expressão "fragilidade financeira" surge nesse modelo como uma tendência do comportamento das firmas em uma economia de mercado em ampliar a participação dos 
mecanismos de debt-finance no financiamento de seus investimentos, o que as torna mais suscetíveis ao comportamento do mercado financeiro.

12. Nesse modelo, a depreciação não é considerada, ou seja, é nula. Além disso, as empresas só se utilizam de capital produtivo como ativo.

13. O fluxo de renda (R) gerado pela firma cobre o serviço da dívida (V) e o investimento da firma (I), de forma que há espaço para redução de seu endividamento (D). Contudo, uma firma nessa situação pode incorrer em problemas financeiros se os seus rendimentos líquidos declinarem (como nos ciclos econômicos) ou se o seu serviço de dívida crescer (ocorre quando há diminuição do crédito). Nas palavras de Minsky: "Hedge financing units are those which can fulfill all of their contractual payment obligations by their cash flows: the greater the weight of financing in the liability structure, the greater the likelihood that unit is a hedge financing unit" (1992, p. 7).

14. Nesse caso, o fluxo de renda gerado pela firma (R) paga o serviço da dívida (V), mas ela recorre a empréstimos de forma a financiar parte de seus investimentos (I). Quase todas as firmas atravessam essa fase em seu desenvolvimento, desde que firmas consideradas de "sucesso" gerem oportunidades de investimento que excedam sua capacidade de autofinanciamento. Nas palavras de Misnky: “(...) speculative units are units that can meet their payment commitments on 'income account' on their liabilities, even as they cannot repay the principle out of income cash flows. Such units 'roll over' their liabilities” (1992, p. 7).

15. Uma firma nessa situação realiza empréstimos para pagar parte do serviço de sua dívida. Um crescimento no serviço da dívida dessas firmas torna mais difícil a realização de mais empréstimos junto aos credores. Muitas firmas passam por uma fase do tipo Ponzi, como resultado de choques de curto prazo não antecipados em seus rendimentos líquidos ou serviços de dívida. Contudo, elas se tornarão insolventes em um tempo finito dentro de sua trajetória Ponzi. Se os credores não acreditarem no crescimento dos fluxos de rendimentos futuros dessas unidades, eles se recusarão a realizar novos financiamentos. Nas palavras de Minsky: “(...) the cash flows from operations are not sufficient to fulfill either the repayment of principle or the interest due on outstanding debts by their cash flows from operations. (...) A unit that Ponzi finances lowers the margin of safety that it offers the holders of its debts" (1992, p. 7) (Destaque nosso). Essa margem de segurança cobre os erros em relação aos possíveis retornos dos projetos de investimentos, os quais requerem financiamento, a partir da frustração de expectativas.

16. O aumento superior do financiamento interno em relação ao externo ocorre devido à maior velocidade de resposta do sistema bancário endógeno no fornecimento de recursos aos agentes econômicos internos, em um ambiente de sucesso de empreendimentos. Esse ambiente de sucesso de empreendimentos associado à ausência de dificuldades financeiras sérias sobre um período substancial de tempo conduz ao desenvolvimento de uma economia eufórica, na qual o aumento do financiamento de curto prazo de posições de longo prazo torna-se um caminho normal, aumentando o nível de financiamento externo das empresas.

17. No contexto exposto, o nível de endividamento das firmas aumenta mais do que proporcionalmente ao nível dos lucros esperados. Uma hipótese para esse fenômeno se deve ao fato de que os fundos externos emprestáveis pelos bancos se tornam mais escas- 
sos, tendo em vista a grande expansão dos investimentos, de maneira a encarecer o endividamento. Esse fato, ceteris paribus, faz com que as unidades assumam posições cada vez mais especulativas, dada a necessidade desses recursos.

18. Para Minsky, a inovação financeira é uma característica das fases expansionistas das economias capitalistas modernas (Deos, 1997).

19. No mercado de securitização, ocorre o surgimento de mercados secundários para negociar, por meio de títulos, os passivos emitidos a partir de crédito no sistema bancário. No mercado de derivativos, são negociados diversos tipos de riscos associados a um amplo leque de ativos e operações financeiras. Segundo Carvalho (2000) e Lourenço (2006) a revogação da Lei Glass-Steagal, a qual permitia a segmentação da atividade bancária entre comercial e de investimento, fez com que o setor bancário adotasse práticas arriscadas de concessão de recursos, aumentando os conflitos de interesse entre tomadores de crédito, bancos e Federal Reserve, uma vez que deu maior permissividade à prática na qual um mesmo banco podia fornecer recursos e ao mesmo tempo emitir títulos mobiliários, por exemplo.

20. Vale salientar que o boom nos investimentos e nos mercados financeiros é acompanhado por um boom no mercado de ações, o que estimula as firmas que têm suas ações valorizadas no mercado a assumir mais passivos.

21. A hipótese subjacente ao aumento da taxa de juros se deve, por exemplo, à possibilidade de pressões inflacionárias serem combatidas com o uso desse mecanismo. Vale notar que essa possibilidade, como evidenciado, não é contemplada por Minsky em sua última fase.

22. Nas palavras de Skott, "the system is fragile if small disturbances - an unforeseen drop in income, for instance, or a rise in interest rates - would make it difficult or impossible for a significant proportion of the financial units to meet their contractual obligations" (1995, p. 25). Para Dymski e Pollin (1992), a fragilidade financeira se refere "a um estado do sistema econômico, e a instabilidade tem a conotação de um (ou vários) processo(s) afetando este sistema". Quando os compromissos financeiros de uma economia crescem em relação a seus recebimentos, significa que a economia encontra-se em estado de maior fragilidade. Por outro lado, quando distúrbios na estrutura financeira da economia, como um crash no mercado de ações, falência bancária significativa ou não pagamento de débitos externos, afetam o nível de atividade real da economia, ela encontra-se em estado de instabilidade financeira.

23. Esse fato decorre da ação direta do Big Bank e do Big Government sobre a estrutura do sistema financeiro, em termos de saneamento do sistema e de exigência de menores níveis de alavancagem e exposição ao risco, por exemplo.

24. Segundo Lourenço (2006, p. 468) “(...) versões mais antigas do conceito pareciam querer dar conta da própria temporalidade do ciclo, localizando-o em um período de 10 a 15 anos, além de dissociá-lo de um ciclo de período menor, guiado pela interação acelerador-multiplicador. Isso sugere, portanto, uma visão muito mais estrita do fenômeno cíclico do que aquela proposta (...)" (por Minsky). Na sequência, o autor complementa: “(...) com o tempo, porém, a ênfase da argumentação foi se deslocando desse conceito mais 
estrito para uma visão mais atenta às duas 'importantes configurações invariantes', isto é, para uma visão mais qualitativa e menos mecânica do movimento cíclico. Simultaneamente, a distinção entre os dois processos foi eclipsada" (Lourenço, idem). Ainda assim, “(...) qualquer que seja a forma específica de interpretação atribuída à dinâmica cíclica do capitalismo é que esta depende essencialmente do comportamento do investimento".

25. As expressões Big Bank e Big Govenment foram cunhadas por Minsky (1986). No caso do Big Government, Minsky mostra de que forma o gasto governamental anticíclico de um setor público com participação significativa na demanda agregada pode conter a tendência à deflação de dívidas que surge na crise. O Big Bank, por sua vez, é um Banco Central que intervém como emprestador de última instância, fornecendo liquidez para que os bancos possam conceder crédito às empresas, evitando, assim, que elas deixem de pagar seus empréstimos e fechem. Para intervir dessa forma, o Banco Central deve fornecer a liquidez necessária para atender aos fluxos de caixa financeiramente frágeis, e os participantes do mercado devem perceber que esse Banco Central está disposto a desempenhar esse papel.

26. Lourenço (2006), ao analisar a HIF, verificou que o grau de endogeneidade por trás da crise financeira variou ao longo do período de produção acadêmica de Minsky. Em uma segunda fase de pesquisa de Hyman P. Minsky, que vai de 1965 a 1990, Lourenço (2006) destaca que o avanço do processo de fragilização financeira endógena é condição necessária, mas insuficiente per se, para a ocorrência de uma reversão cíclica. Já em uma terceira fase (1990-1996), Lourenço (2006) advoga que é perceptível uma redução da ênfase na necessidade de choques exógenos como elementos essenciais para a geração de uma crise financeira, em que é recuperada a interpretação de não linearidade dos ciclos em uma nova base.

27. Esse ponto é destacado também por Lourenço (2006).

28. Dymski e Pollin (1992) e Dymski (2004) ligam duas vertentes de pensamento que Minsky deixou desvinculadas. Esses autores, em seus respectivos trabalhos, afirmam que a fragilidade e a instabilidade financeira de uma economia dependem não apenas dos fatores do ciclo econômico, como Minsky ressaltou, mas também das tensões entre o setor real e o financeiro. Além disso, o surgimento de bolhas de ativos e tendências de crise financeira depende, em parte, dos mecanismos institucionais utilizados pela economia para canalizar os capitais em direção às opções de investimento.

29. Além disso, Dymski (2004) ressalta que o modelo básico de Minsky não leva em conta as consideráveis dificuldades que podem resultar da relação entre conta corrente e reservas. Conforme já salientado, o modelo maduro de Minsky focalizou uma economia fechada, porque, para ele, os Estados Unidos eram o caso emblemático de grande economia com mercados financeiros sofisticados. Em razão dos desequilíbrios que podem surgir nos fluxos financeiros entre países, pode ser que haja uma crise à la Minsky (de fragilidade financeira) mesmo sem ter ocorrido um ciclo econômico como o proposto originalmente por esse autor. Dymski (2004) desenvolve um trabalho a partir do arcabouço teórico de Minsky, para explicar o papel das bolhas no processo de criação, propagação e resolução de crises financeiras a partir de uma abordagem espacializada, ou seja, a partir das especificidades das fronteiras cambiais e relações econômico-financei- 
ras entre os diferentes países. Nesse sentido, esse autor expande o modelo básico de expansão-contração elaborado por Minsky, a partir de sua estrutura central para explicar a crise financeira no Japão e na Coreia do Sul. Um corolário importante desse trabalho é demonstrar que as bolhas e crises financeiras podem ser resultado de processos econômicos de importação de capital em que a taxa de crescimento dos direitos financeiros sobre os ativos de capital excede a taxa de crescimento de ativos reais.

30. Esse foi o caso, por exemplo, do maior banco dos Estados Unidos, o Citigroup, que contabilizou US\$ 22 bilhões de prejuízo com investimentos e empréstimos frustrados de crédito imobiliário. Segundo dados apurados pelo Fundo Monetário Internacional (FMI), o prejuízo foi o primeiro desde a criação do Citigroup, em 1998, resultado da fusão do Citicorp com o Travelers Group. Levando em conta apenas a história do Citi, foi a primeira perda em 17 anos e a maior em seus 196 anos de história. O banco americano de investimentos Merrill Lynch, por sua vez, registrou um prejuízo líquido de US $\$ 9,8$ bilhões no quarto trimestre de 2007, com o peso da perda de US\$11,5 bilhões no valor de títulos ligados ao mercado de créditos de risco. No mesmo trimestre de 2006, o banco havia registrado um lucro de US\$2,35 bilhões. O Banco JP Morgan anunciou queda de $34 \%$ em seu lucro no último trimestre de 2007. No mesmo trimestre de 2006, o banco havia registrado um lucro de US\$2,35 bilhões.

31. Em relação a esses tipos de financiamento e empréstimos: “(...) most of these loans originated without proper documentation as to the borrower's income, wealth, and employment status. Thus, the information that would have been required to make a credit assessment based on scoring was not available, and in many cases, it was fabricated" (Kregel, 2007, p. 13).

32. Estima-se, hoje, que as dívidas inadimplentes cheguem a US\$ 460 bilhões. Contudo, após a retomada dos imóveis, deverá ser reduzido a algo próximo de US\$ 113 bilhões (Stiglitz, 2006).

33. O jargão utilizado no mercado para essa situação é home-equity withdrawal' (ou operações de housing equity withdrawal) e pode ser entendido como uma situação em que as dívidas hipotecárias no agregado crescem mais do que o gasto líquido com ativos imóveis (como casas e apartamentos). A situação oposta é chamada de "housing equity injection”. Para mais informações a respeito dessas operações no Reino Unido e Estados Unidos, ver o Reserve Bank of Australia Bulletin (vários números) e Bernanke (2007), ou ainda o artigo "Mortgage equity withdrawal and consumption" do Banco da Inglaterra, publicado no Quartely Bulletin, 2001, p. 100-103.

34. Os Estados Unidos cresceram, em 2002, 1,6\%, em 2003, 2,6 \%; em 2004, 3,6\%; em 2005, 3,1\%; em 2006, 2,9\%. Para 2007 e 2008, a expectativa é de 1,9\% (dados do FMI).

35. Um segundo mecanismo, enfatizado por Schaferstein e Stein (1993), parte do princípio de que existem ganhos de reputação associados ao seguimento da opinião média prevalecente no mercado. Tais ganhos são particularmente relevantes em um ambiente institucional caracterizado por (i) separação entre propriedade do capital e gestão das empresas e (ii) informação assimétrica a respeito da "qualidade média" dos gerentes de empresas. Nesse sentido, no ambiente institucional vigente é melhor para os 
gerentes de empresas e carteira "fracassar junto com o mercado do que vencer contra ele” (Keynes, 1936, p. 130). Nesse sentido, a partir do momento em que existe algum tipo de convenção otimista no mercado a respeito do futuro, os bancos concedem mais empréstimos e financiamentos para tomadores de recursos mais arriscados, acabando por diminuir a margem de segurança das operações, simplesmente porque os outros bancos também o fazem. Daí abre-se margem para a concentração de risco e sobreinvestimento na economia.

36. Essa teoria explica em parte por que as pessoas tendem a buscar qualificação, uma vez que formadas tendem a possuir maior renda permanente do que as que não possuem essa qualificação. Além disso, segundo Friedman (1957), a renda corrente seria o somatório de dois elementos: a renda permanente e a renda temporária. Enquanto a renda permanente seria a parte da renda que as pessoas esperam manter no futuro (como um ativo imóvel), a renda temporária seria a parte da renda que elas não esperam manter no futuro (o fluxo de salários do mercado de trabalho em determinado período, o qual é variável em uma série para um determinado indivíduo, por exemplo). Em outras palavras, a renda permanente seria a renda média, e a renda transitória seria o desvio em relação a essa média.

37. Esse processo é chamado de "housing equity withdrawal". Cf. nota 33.

38. De maneira geral, a margem de segurança pode ser realizada por parte do valor das garantias pignoratícias ou subsidiárias (collateral) dadas pelo agente, neste caso o imóvel. Contudo, o valor desse ativo entrou em queda abrupta nos Estados Unidos.

39. A oferta de crédito afeta os preços dos imóveis.

40. O nível de investimento em relação ao PIB chegou a seu pico em 2006 (20\%), com expectativas para 18\% em 2007 e 2008 (dados do FMI).

41. De acordo com Mishkin (2007, p. 1): “(...) In the United States, rising delinquencies of subprime residential mortgages have led to substantial losses to holders of securities backed by those mortgages and to sharp increases in credit spreads for those securities. Furthermore, problems in the subprime mortgage market have led investors to reassess credit risk and risk pricing, thereby widening spreads in general and weakening the balance sheets of some financial institutions".

42. $\mathrm{Se}=$ Poupança Externa, $\mathrm{TC}=$ Transações Correntes e TK $=$ Transações da Conta de Capital.

43. A relação dessas variáveis está diretamente relacionada à hipótese de instabilidade financeira, cujo fundamento reside na existência de dois conjuntos de preços na economia, o preço de oferta e o preço de demanda dos ativos de capital, apresentados na seção 1.

44. Para mais detalhes, veja nas páginas 9 e10 a dinâmica de endividamento das empresas.

45. Os Estados Unidos são responsáveis por absorver cerca de $75 \%$ dos excedentes mundiais de poupança.

46. Ideia análoga poderia ser colocada em relação às empresas. Para um estudo dessa dinâmica mista dos ciclos e crise financeiras, veja Dymski e Pollin (1992). 


\section{REFERÊNCIAS BIBLIOGRÁFICAS}

AOKI, K.; PROUDMAN, J.; VLIEGHE, G. House Prices, Consumption and monetary policy: a financial accelerator approach. Bank of England Working Paper, Londres: Bank of England, n. 169, 2002.

BANERJEE, A. A simple model of herd behaviour. The Quartely Journal of Economics, v. CVII, n. 3. 1992.

BANK OF ENGLAND. Mortgage equity withdrawal and consumptin. Quartely Bulletin, Spring, p. 100-103, 2001.

BAYOUMI, T.; EDISON, H. Is wealth increasingly driving consumption? DNB Staff Reports, Amsterdam: De Nederlandsche Bank, n. 100, 2003.

BERNANKE, BEN S. GSE portfolios, systemic risk, and affordable housing. Remarks before the independent community bankers of america's annual. Convetion and Techworld, Honolulu, mar. 6, 2007.

CALZA, A.; MONACELLI, T.; STRACCA, L. Mortgage markets, collateral constraints, and monetary policy: do institutional factors matter? CFS Working Paper. Series n. 2007/10. Frankfurt: Center for Financial Studies, 2007.

CARROLL, C.; OTSUKA, M.; SLACALEK, J. How large is the housing wealth effect? A new approach. NBER. Working Paper, Cambridge, Mass.: National Bureau of Economic Research, n. 12.746 , dec. 2006.

CARVALHO, F.; SOUZA, F.; SICSU, J. Economia monetária e financeira: teoria e política. Rio de Janeiro: Campus, 2000.

CASE, K. E.; SHILLER, R.J. Is there a bubble in the housing market? Brookings Papers on Economic Activity, v. 2, p. 299-342, 2003.

; QUIGLEY, J. M.; SHILLER, R.J. Comparing wealth effects: the stock market; versus the housing market. Advances in Macroeconomics, v. 5, n. 1, 2005. Disponível em:<www. bepress.com/bejm/advances/vol5/iss1/art1>

DAVIDSON, P. Post Keynesian Macroeconomic Theory: a foundation for sucessful economic policies for the Twnty-first Century. Aldershot: Edward Elgar, 1994.

DAVIS, M. A.; ORTALO-MAGNÉ, F.; RUPERT, P. What's Really Happening in Housing Markets? [S.l.: s.n.], 2007. (mimeo.)

DAZIEL, P. A post keynesian theory of asset price inflation with endogenous money. Journal of Post Keynesian Economic, v. 22, n. 2, Winter 1999-2000.

DEOS, S. S. de. A hipótese da instabilidade financeira de Minsky numa economia de mercado de capitais. Porto Alegre, 1997. (Dissertação do Mestrado em Economia) - Curso de Pós-Graduação em Economia, Universidade Federal do Rio Grande do Sul, Porto Alegre, 1997.

DYMSKI, G. Bolhas de ativos e crises em Minsky: uma abordagem espacializada. In: FERRARI FILHO, F.; PAULA, L. F. Globalização financeira: ensaios de macroeconomia aberta. Petrópolis: Vozes, 2004. 
DYMSKI, G.; POLLIN, R. Hyman minsky as hedgehog: the power of the Wall Street paradifm. In: FAZZARI, S.; PAPADIMITRIOU, D. (Ed.). Financial Conditions and Macroeconomic Performance. Nova York: M. F. Sharpe, 1992.

Economia de bolha e crise financeira no Leste Asiático e na Califórnia: uma perspectiva espacializada de Minsky. Economia e Sociedade, Campinas, n. 11, dez. 1998.

FERRI, P. From Business Cycles to the economics of instability. In: FAZZARI, S.; PAPADIMITRIOU, D. (Orgs.). Financial Conditions and Macroeconomic Performance: Essays in Honor of Hyman P. Minsky. Londres: M. E. Sharpe, 1992.

FMI (IMF). Global Financial Stability. Washington D.C.: International Monetary Fund, mar., 2007.

FOLEY, D. Financial fragility in developing economies. In: DUTT, A. K.; ROS, J. (Eds.). Development Economics and Structuralist Macroeconomics. Aldershot: Edward Elgar, 2003.

FRIEDMAN, M. A Theory of the Consumption Function. Princeton, N. J.: Princeton University Press: 1957.

KEYNES, J. M. Teoria geral do emprego, do juro e da moeda. São Paulo: Atlas [Edição Original: 1936].

KREGEL, J. Minsky's Cushions of Safety: systemic risk and the crisis in the U.S. subprime mortgage market. [S.1.]: Public Policy Brief. Levy Institute, 2007.

LOURENÇO, A. L. C. de. O pensamento de Hyman P. Minsky: alterações de percurso e atualidade. Economia e Sociedade, Campinas, v. 15, n. 3, p. 445-474, dez. 2006.

MINSKY, H. P. John Maynard Keynes. Nova York: Columbia Univerty Press, 1975.

Can "it" Happen Again? Essays on Instability and Finance. Armonk, NY: M. E. Sharpe, 1982.

- Stabilizing an Unstable Economy. NovaHaven: Yale Univerty Press, 1986.

The Financial Instability Hypotesis. Nova York: The Nova Economics Institute, 1992 (Working Paper, 74). Disponível em: <http://www.levy.org>.

Integração financeira e política monetária. Economia e Sociedade, Campinas, n. 3, dez. 1994.

MISHKIN, F. S. Housing and the Monetary Transmission Mechanism. Finance and Economics Discussion Series Divisions of Research \& Statistics and Monetary Affairs Federal Reserve Board, Washington, D. C., 2007.

PAPADIMITRIOU, D. B.; HANNSGEN, G.; ZEZZA, G. The effects of a declining housing market on the U.S. Economy. The Levy Economic Institute, WP 506, jul. 2007.

SCHARFSTEIN, D.; STEIN, J. Herd behaviour and investment. The American Economic Review, jun. 1993.

SHILLER, ROBERT J. Long-Term perspectives on the current boom in home prices. The Economists Voice, v. 3, n. 4, Article, 2006.

SKOTT, P. Financial innovation, deregulation and Minsky cycles. In: EPSTEIN, EDSYG.; GINTIS, H. Macroeconomic Policy After the Conservative Era. Cambridge: CUP, 1995. cap. 9. 
STIGLITZ, J. The USA GDP. [S. 1.: s. n.], 2006. (mimeo.)

TAYLOR, L.; O'CONNEL, S. A minsky crisis. Quartely Jounal of Economics. Cambridge, Issue Supplement, n. 100, p. 871-885, 1985.

WOLFSON, M. H. Minsky's theory of financial crises in a global context. Journal of Economic Issues, Lewisburg: Bucknell University, v. XXXVI, n. 2, jun. 2002.

WYNNE, GODLEY; PAPADIMITRIOU, DIMITRI B.; ZEZZA, GENARO. The US.s Economy: what's next? Strategic Analysis. Annandale-on-Hudson, NY: The Levy Economic Institute of Bard College, 2007. 